\title{
Hva kan leger lære av Jesus?
}

Uavhengig av om vi har en personlig tro på Jesus som Herre og Frelser, kan vi ha ham som rollemodell og følge hans eksempel i møte med pasienter og kolleger. Hvilke konsekvenser kan det ha dersom vi følger Jesu eksempel?

Jesu omsorg for de syke kommer blant annet til uttrykk i det som ofte omtales som hans «programtale», der han blant sine oppgaver nevner at blinde skal få synet igjen (1). Ifølge Bibelen omtalte også Jesus to ganger seg selv som lege $(2,3)$.

\section{...forkynne ordet og helbrede syke} Jesus var ikke bare opptatt av å forkynne. Jesus var også opptatt av å dekke menneskers behov her og nå. Dette inkluderte å helbrede syke (4). Altså engasjerte han seg i hele mennesket: både det kroppslige og det åndelige. Som leger må vi også være opptatt av det hele mennesket. For oss er utfordringen riktignok motsatt av kirkens utfordring, for de troende kan komme til kun å fokusere på det åndelige og å glemme det jordiske og praktiske. Selv om den biopsykososiale modellen terpes i medisinstudiet, kan vi i klinisk praksis lett bli fanget av reduksjonisme. Selv om tidspresset er stort, bør vi i mange situasjoner heller utvide til en bio-psyko-sosio-spirituell modell dersom vi skal ta pasientene på alvor som hele mennesker (5).

\section{...gå derfor bort og synd ikke mer}

Jesus var tydelig. Både på hva som var galt og på at ingen var feilfrie, men mennesker som hadde feilet møtte han på en slik måte at de ikke opplevde seg fordømt. I møtet med kvinnen som var grepet i ekteskapsbrudd sa han ikke at ekteskapsbrudd var greit, tvert imot (6). Men i tillegg sa han at den som var uten skyld kunne kaste den første steinen. Historien fortsetter med at alle tilhørerne gikk bort, de eldste først.

En lege møter pasienter som må ta konsekvensene av levd liv. Vi møter kolleger som gjør feil, og vi møter annet helsepersonell som gjør feil. Og vi gjør feil selv. Det er forskjell på å påpeke ting som skulle vært gjort annerledes og det å fordømme. Det vi må gjøre, er å hjelpe pasienter og hverandre

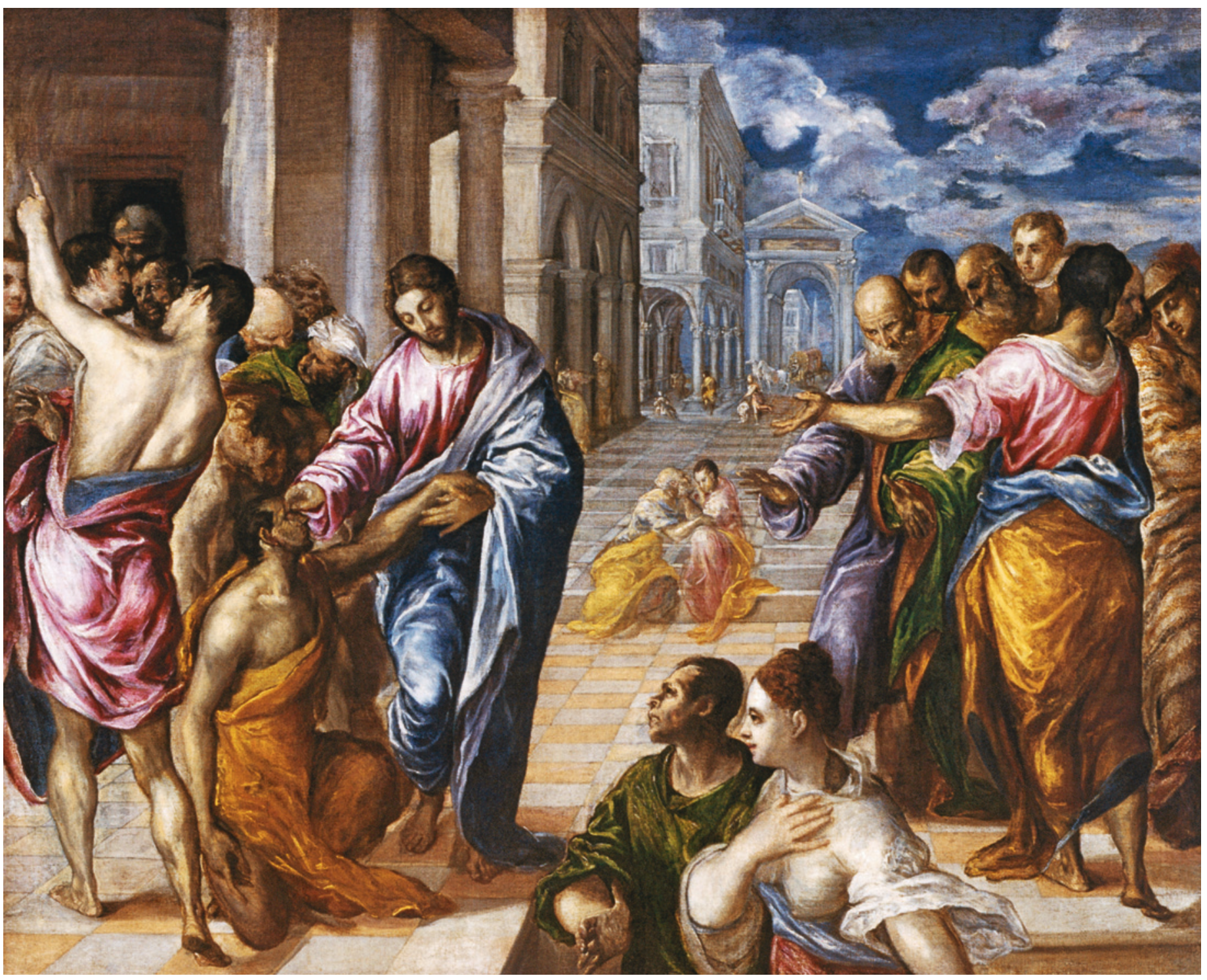


til en ny start slik at fortsettelsen kan bli bedre. Vi må møte andres feiltrinn slik vi ønsker at andre skal møte våre feiltrinn.

\section{...det du gjør mot en av disse mine minste}

Jesus identifiserte seg med de små og svake og oppfordret sine tilhengere til å ta særlig vare på dem (7). Hvem er våre minste $\mathrm{og}$ svakeste? Her hjemme kan det være rusmisbrukere, pasienter med sammensatte tilstander som faller utenfor den høyspesialiserte og organfokuserte helsetjenesten eller pasienter med andre lavstatussykdommer. Mennesker er også på sitt svakeste i livets spede begynnelse og ved livets slutt. Det å arbeide for de svake gruppene, både klinisk og fagpolitisk, er å følge i Mesterens fotspor. Dersom vi løfter blikket utover Norges grenser, ser vi enda flere grupper: de som rammes av dårlig eller ikke-eksisterende svangerskapsomsorg, de som ikke har råd til grunnleggende medisiner, de som dør av dehydrering og mange flere. Selv om det ikke bare er akseptabelt, men ofte etisk høyverdig av norske klinikere å kjempe for mer ressurser til sine pasienter, må vi ha i bakhodet at de samme hendene og de samme pengene også kan brukes andre steder.
Kostnaden er høy når man skal gjøre mer for dem som allerede har mye.

\section{...han fikk inderlig medfølelse med dem}

I en travel klinisk hverdag opplever vi noen ganger at vi blir harde. Vi ser ikke lenger mennesket og lidelsen, kun diagnosen. $\mathrm{Og}$ noen ganger blir vi mer opptatt av å verne om oss selv og egne rettigheter enn av hvordan vi best kan hjelpe pasientene. Jesus ble dypt berørt i sine møter med syke og lidende mennesker: «han fikk inderlig medfølelse med dem og helbredet de syke blant dem» (8). At han ble berørt, førte altså til handling, at han helbredet sykdommene deres.

Legen må også la seg berøre av mennesker. Og blir vi berørt, får det konsekvenser for hvordan vi ser og møter pasientene. Det å engasjere seg i mennesket fremfor diagnosen kommer pasientene til gode, men det gjør også legegjerningen mer givende.

Olav Magnus S. Fredheim

olav.m.fredheim@ntnu.no
Olav Magnus S. Fredheim (f. 1979) er lege i spesialisering i anestesiologi ved Oslo universitetssykehus, Rikshospitalet. Han er ph.d. i smertemedisin og arbeider som forsker ved Norges teknisk-naturvitenskapelige universitet og Nasjonal kompetansetjeneste for sammensatte lidelser. Han er også leder for sentralstyret i Norges kristelige legeforening. Forfatter har fylt ut ICMJE-skjemaet og oppgir ingen interessekonflikter.

\section{Litteratur}

1. Bibelen. Lukas 4,18.

2. Bibelen. Matteus 9,12.

3. Bibelen. Lukas 4,23.

4. Bibelen. Lukas 9,2

5. Magelssen M, Fredheim OM. En åndelig dimensjon er viktig for mange pasienter. Tidsskr Nor Legeforen 2011: 131: 138-40.

6. Bibelen. Johannes 8,11.

7. Bibelen. Matteus 25,14.

8. Bibelen. Matteus 14,14.

Mottatt 14.8. 2012, første revisjon innsendt 11.9. 2012, godkjent 17.9. 2012. Medisinsk redaktør Erlend Hem.

Publisert først på nett 7.12. 2012 